\title{
Conservation of (Lagunaria Patersonii) with using in Vitro and in Vivo Propagation
}

Mai A. Ibrahim ${ }^{1}$, Naglaa M. Esmaiel ${ }^{1}$ and Abido ${ }^{2}$ A.I.A.

1. Floriculture Department, Horticulture institute, Agricultural Research Center, Alexandria, Egypt

2. Plant Production Department, the Faculty of Agriculture - Saba Basha, Alexandria University, Egypt

ABSTRACT: Lagunaria (Lagunaria patersonii) is considered to be a nearly threatened tree in Egypt where there are only few trees facing a very high risk of extinction owing to the effects of pathogens, pollutants and parasites. Hence, this study was conducted to establish a fast in vitro propagation protocol. Seeds, lateral buds and shoot tips were cultured on MS, NN and N6 media with different concentrations of BAP and NAA and their combinations. Results indicated that the optimum medium for the measured characters was MS free growth regulators and The best rooting medium was $1 / 4$ MS. RAPD analysis was also applied to detect the genetic polymorphism among Lagonaria plantlet and their original parents.

Key words: Lagunaria patersonii, nearly threatened, in vitro, in vivo propagation and RAPD analysis

\section{INTRODUCTION}

Al Nozha, Antoniades and Rose gardens which located in Alexandria, Egypt are considered from the oldest gardens all over the world in terms of design, construction and wealth of ornamental trees, shrubs, palms and other herbaceous flowering plants. Al Nozha garden goes back to the era of Ptolemy. It was created 300 years B.C. Nowadays, the gardens lost, throughout the years, many genera of this collection; some of them are now considered neither very rare or nearly threatened plant genera, in which very few samples are only left overall Egypt as Lagunaria (Lagonaria patersonii) as reported by (USFWS, 2006 and Theresa, 2010). It is a dioecious plant native to Australia, an ornamental and amenity tree related to family Malvaceae. Commonly known as the pyramid tree, Norfolk island hibiscus, or Queen island white oak, semi salt and drought tolerant (John, 2006). There are only few trees of Lagunaria patersonii which are going to be extinct due to the infection with insects as cotton seed bugs (Oxycarinus hyalinipennis) (USDA, 2006) and/or fungus as Rhizoctonia solani (Aiello et al., 2008). The vegetative propagation of this plant by usual horticultural methods is difficult. Rooting of cuttings, besides being slow, requires considerable controlled greenhouse facilities. Furthermore, there are certain other horticultural limitations, since via particular elite individual only few cuttings can be obtained and the rooting can be achieved only if the cuttings of newly hardened terminal shoots are taken during a particular period of the year (Chaturvedi and Sharma, 1989). In these consequences, an alternative mass propagation system like in vitro propagation technology can efficiently be applied to save this rare important plant to meet up the demand for this genus as well as for future conservation. The present investigation was conducted to determine a suitable protocol to regenerate the above mentioned endangered plant (Lagunaria patersonii) throughout tissue culture technique. In addition, the molecular marker tool using Random Amplified Polymorphic DNA (RAPD) analysis was also 
applied to detect the genetic polymorphism among Lagonaria plantlets and their original parents.

\section{MATERIALS AND METHODS}

The present work was carried out at the Tissue Culture Laboratory, Horticulture Research Institute (HRI), Agricultural Research Center (ARC), Antoniades Gardens, Alexandria.

\section{Plant material and culture conditions ( In vitro experiment)}

Seeds, lateral buds and shoot tips were obtained from the old trees grown in Antoniades Gardens, Smouha, Alexandria. Various explants were surface sterilized with $70 \%$ ethanol for a minute, followed by immerging in either $0.1 \%(\mathrm{w} / \mathrm{v})$ Mercuric chloride $\left(\mathrm{MgCl}_{2}\right)$ or Clorox $(\mathrm{NaClO})$ at $5 \%(\mathrm{w} / \mathrm{v})$, for 5,10 or $15 \mathrm{~min}$, then washed with six changes of sterile distilled water. The explants were, aseptically, placed on agar-solidified (Murashige and Skoog , 1962) basal medium (MS), N6 (CHU1975) and (Nitsch and Nitsch, 1969) media(NN) containing 3\% sucrose. All media were adjusted to $\mathrm{pH} 5.8$ at $25^{\circ} \mathrm{C}$ with $\mathrm{NaOH}$ and/ or $\mathrm{HCl}$ and were autoclaved for 20 min. at $121^{\circ} \mathrm{C}(15 \mathrm{PSI}$ nominal steam pressure). The cultures were incubated for four weeks in a $16 \mathrm{~h}$ light and $8 \mathrm{~h}$ dark cycle at $25 \pm 2^{\circ} \mathrm{C}$ and were illuminated with fluorescent light at 2000 lux. Other additions (mg/l) were common in the culture media as 2.0 Glycine, 100.0 myo-inositol, 5.0 nicotinic acid, 10.0 pyridoxine $\mathrm{HCl}$, 10.0 thiamine $\mathrm{HCl}, 5800$ agar , 2000 activated charcoal(AC).

\section{Shoot and root induction responses}

Explants were cultured on seven media protocols (Table 1) .Shoot induction response was recorded and the shoot length $(\mathrm{cm})$, number of leaves were recorded. Shoots with 4 - 6 leaves were transferred to 1/4 MS hormone free as a rooting medium. Rooted plantlets were removed from the jars, and agar was washed from roots, then the plantlets were transplanted into small pots filled with peat moss and covered with polyethylene bags. The plants were transferred to greenhouse where they were placed under mist for 4 weeks then to an open shade house.

Table (1). Culture media of Lagunaria patersonii explants

\begin{tabular}{c|l}
\hline Medium protocol & \multicolumn{1}{c}{ Content } \\
\hline 1 & MS free growth regulator medium \\
2 & MS+0.4 mg/l BA \\
3 & $3 / 4$ strength MS medium \\
4 & $1 / 2$ strength $\mathrm{MS}$ \\
5 & $1 / 4$ strength $\mathrm{MS}$ \\
6 & $\mathrm{~N} 6$ basal medium $+0.4 \mathrm{mg} / \mathrm{l} \mathrm{BA}$ \\
7 & (NN) medium and $0.4 \mathrm{mg} / \mathrm{BA}$ \\
\hline
\end{tabular}




\section{Statistical analysis}

Collected data were, statistically, analyzed as a 4 factors experiment (explants, medium protocols, sterilization methods and sterilization times) in a completely randomized design with 6 replicates. All data were subjected to arcsine transformation prior to statistical analysis (Steel and Torrie, 1980). Comparisons among means were made using the least significant differences test (LSD). The data were analyzed using (SAS, 1985) program version 6.

\section{In vivo experiment}

Explants (seeds, lateral buds and shoot tips) of Lagunaria were collected and cultured on a monthly experiment starting from January till December 2013 to determine the best time for propagation and germination. Explants were cultured in trays filled with soil mixture (Table 2). Before planting, explants were immersed in either different concentrations of IBA solution $(0.0$ to $10 \mathrm{ppm})$ for 30 seconds or in 10 $\mathrm{ml}$ of the commercial rooting hormone Crop plus for $1 \mathrm{~min}$. After 6 weeks, shootlet length $(\mathrm{cm})$, root number and root length $(\mathrm{cm})$ were measured for each cultured explant.

Table (2). Soil mixtures composition used for Lagunaria in vivo propagation

\begin{tabular}{cl}
\hline No. & \multicolumn{1}{c}{ Composition } \\
\hline 1 & $100 \%$ Peat moss \\
2 & $100 \%$ Berlite \\
3 & $100 \%$ Sand \\
4 & $1: 1(\mathrm{v} / \mathrm{v})$ Peat moss: Berlite \\
5 & $1: 1(\mathrm{v} / \mathrm{v})$ Peat moss: Sand \\
6 & $1: 1(\mathrm{v} / \mathrm{v})$ Berlite: Sand \\
7 & $1: 1: 1(\mathrm{v} / \mathrm{v} / \mathrm{v})$ Peat moss: Berlite: sand \\
\hline
\end{tabular}

\section{Molecular Marker analysis}

\subsection{DNA isolation:}

Frozen young leaves of ten plantlets and the main mother plant of Lagunaria were ground to a powder in a mortar with liquid nitrogen. DNA was isolated from 60 $\mathrm{mg}$ of the grinded leaves tissues using i-genomic plant DNA extraction mini kit (iNTRON Biotechnology, Inc, catalog No. 17371) according to their manufacturer instruction. DNA concentration was adjusted at $25 \mathrm{ng} / \mu \mathrm{l}$.

\subsection{PCR amplification}

Ten random primers were used for RAPD analysis for Lagunaria patersonii. The primer sequences were constructed by (Metabion LTd.) Company, UK. The lyophilized primers were dissolved in de-ionized sterile water at a $100 \mu \mathrm{M}$ concentration. The PCR amplification reactions were performed in a volume of $25 \mu \mathrm{l}$. Using $50 \mathrm{ng}$ DNA and $0.5 \mu$ moles of the primer, $100 \mu \mathrm{M}$ of dNTPs, $5 \mu \mathrm{l}$. (1X) of Taq polymerase buffer, $1.5 \mathrm{mM} \mathrm{Mgcl} 2$ and $0.75 \mathrm{U}$ Taq DNA polymerase (Promega). The PCR program included a denaturation step at $94^{\circ} \mathrm{C}$ for 4 minute followed by 35 cycles of $94^{\circ} \mathrm{C}$ for $1 \mathrm{~min}, 30^{\circ} \mathrm{C}$ for $50 \mathrm{sec}$ and $72^{\circ} \mathrm{C}$ for 1 minute, a final extension step at $72{ }^{\circ} \mathrm{C}$ for 7 minute. The PCR products were separated on $1.5 \%$ agarose gel electrophoresis. 
Table (3). Primers names, sequences for RAPD markers for Lagunaria patersonii

\begin{tabular}{cccc}
\hline No. & Primer name & 'rimer sequence (5'-3') & . C content (\%) \\
\hline 1 & & & \\
2 & OPA-03 & AGTCAGCCAC & 60 \\
3 & OPA-05 & AGGGGTCTTG & 60 \\
4 & OPA-07 & GAAACGGGTG & 60 \\
5 & OPA-09 & GGGTAACGCC & 70 \\
6 & OPB-10 & CTGCTGGGAC & 70 \\
7 & OPB-12 & CCTTGACGCA & 60 \\
8 & OPC-07 & GTCCCGACGA & 70 \\
9 & OPC-07 & CTCACCGTCC & 70 \\
10 & OPW-03 & GTCCGGAGTG & 70 \\
\hline
\end{tabular}

\section{Data handling and cluster analysis}

Data were scored for computer analysis on the basis of the presence of the amplified products for each primer. If a product was present in a sample, it was designated as " 1 ", if absent, it was designated as " 0 ", after excluding the nonreproducible bands. Pair-wise comparisons of cultivars, based on the presence or absence of unique and shared polymorphic products, were used to determine similarity coefficients, according to Jaccard (1980).

\section{RESULTS AND DISCUSSION}

\section{In vitro culture and plant regeneration}

Data presented in Table (4) and also Figures (1a, 1b, 1c and 1d) declared that medium protocols combination exerted significant effect on shoot length trait. Regarding the main effect of variables under the study for the shoot length $(\mathrm{cm})$, the medium protocol (1, MS medium) achieved the highest mean value of the given trait $(0.98 \mathrm{~cm})$. This finding could be attributed to the achieve the best combination of nutrients composition and $\mathrm{pH}$, which reflected on the physiological responses of cultured explanted.

On the other hand, the explants tested, revealed that lateral buds recorded the highest mean value $(0.81 \mathrm{~cm})$ this could be due to the organized tissues of the given explant (i.e. shoot tip and same leaf primordial ;which brought about the proliferation of these pre-existing shoots of cultured explantes (lateral bud).likewise using mercuric chloride at $0.1 \%$ as sterilization method led to the highest mean value of the given trait $(0.49 \mathrm{~cm})$.this event may be taken place due to the efficacy of this sterilant agent in surface decontamination of cultured explant. 
Also, the surface sterilization for $15 \mathrm{~min}$. was efficient to achieve the best surface sterilization for cultured explants $(0.69 \mathrm{~cm})$.this results could be explanted as the contact between the external tissue and mercuric chloride, which allow the best disinfection.

With regard to the combination between the tested variables, results of Table (4) demonstrated that cultured seeds $X$ medium protocol (1),mercuric chloride $(0.1 \%) X$ medium protocol (1), and sterilized for $15 \mathrm{~min} X$ medium protocol (1),led to the highest mean value for the given trait.

In the same respect, data of Table(5), divulge that the combination between the tested explant (lateral bud)X mercuric chloride $(0.1 \%)$, and lateral bud as explant with sterilization time for $15 \mathrm{~min}$. achieved the highest mean.

Table (4). Means of shoot length (cm) of Lagunaria as influenced by medium protocol, explant, sterilization method, sterilization time and their interactions

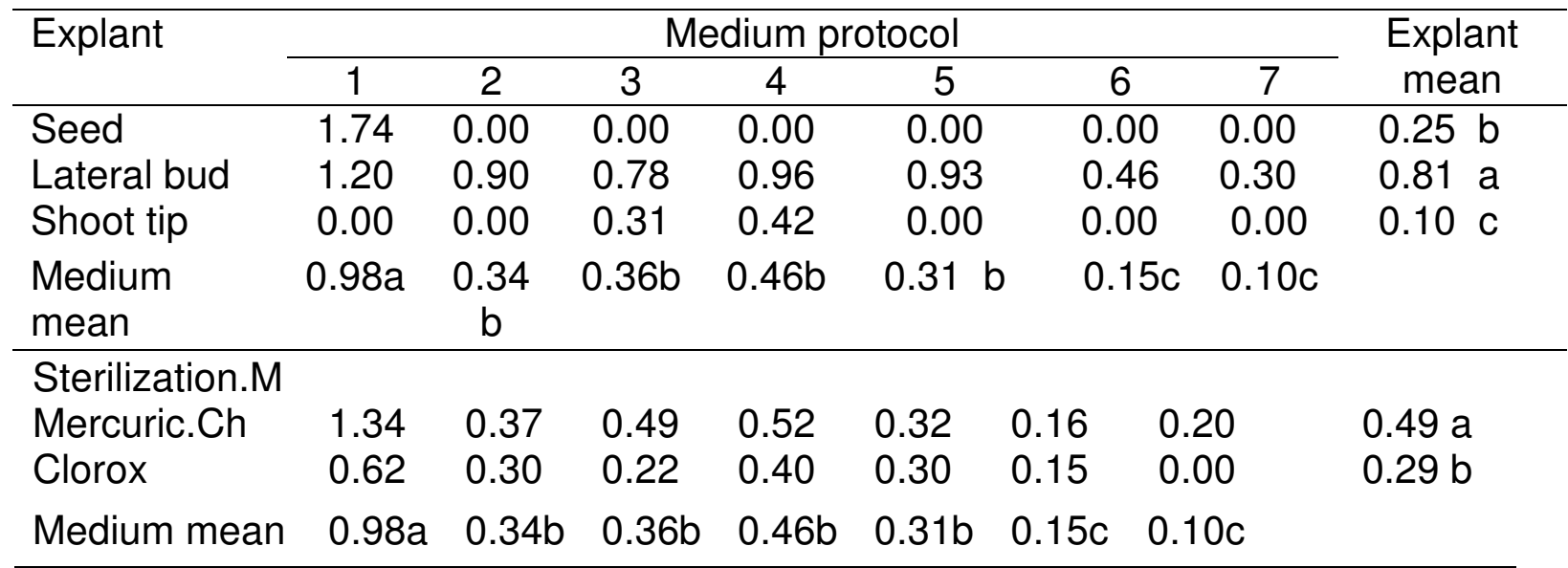

Sterilization .T

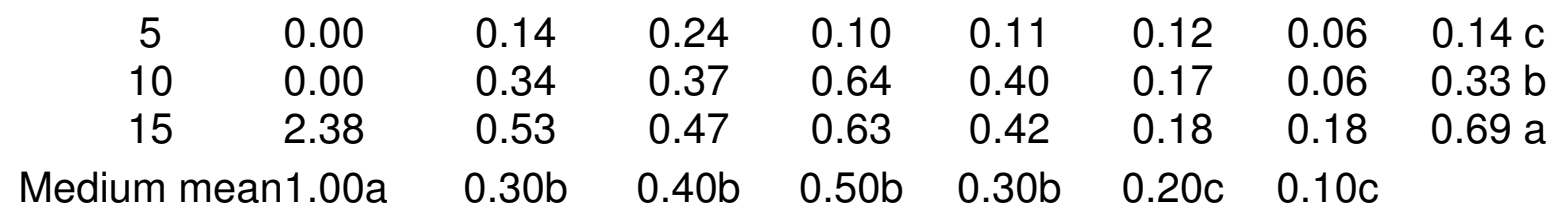

Means followed by the same letters(s) are not significantly different at $0.05 \%$ level of probability.

\subsection{Leaves number}

Table (6) declared that medium protocols $(1,3,4)$ gave rise to the highest mean value of leaves number, medium protocol (1) was (1.30), medium protocol (3) was (1.40) and medium protocol (4) was also (1.50). Lateral buds produced the highest mean value of leaves number (2.25) across medium protocols. The effect of interaction between medium protocols and explants, the highest mean value of leaves number (3.58) this when culture lateral buds on medium protocol (1). The sterilization for $15 \mathrm{~min}$ was the best time producing the highest mean value of leaves number (1.47), the interaction between medium protocols (1) and sterilization time (15 min), gave the greatest mean value of leaves number (2.36). 
Table (5). Means of shoot length $(\mathrm{cm})$ of lagonaria as influenced by explant, sterilization method, sterilization time, and their interactions

\begin{tabular}{|c|c|c|c|c|}
\hline \multirow[t]{2}{*}{ Explant } & \multicolumn{2}{|c|}{ Sterilization method } & & \multirow{2}{*}{ Explant mean } \\
\hline & $\begin{array}{l}\text { Mercuric } \\
\text { chloride }\end{array}$ & Cloro & & \\
\hline Seed & 0.32 & 0.17 & & $0.25 \mathrm{~b}$ \\
\hline Lateral bud & 1.03 & 0.58 & & $0.81 \mathrm{a}$ \\
\hline Soot tip & 0.11 & 0.10 & & $0.10 \mathrm{c}$ \\
\hline \multirow[t]{3}{*}{$\begin{array}{l}\text { Sterilization method } \\
\text { mean }\end{array}$} & $0.49 \mathrm{a}$ & 0.29 & & \\
\hline & \multicolumn{3}{|c|}{ Sterilization time (min) } & \\
\hline & 5 & 10 & 15 & \\
\hline Seed & 0.00 & 0.00 & 0.75 & $0.25 b$ \\
\hline Lateral bud & 0.35 & 0.84 & 1.23 & $0.81 \mathrm{a}$ \\
\hline Shoot tip & 0.07 & 0.15 & 0.08 & $0.10 \mathrm{c}$ \\
\hline Sterilization time mean & $0.10 \mathrm{c}$ & $0.30 \mathrm{~b}$ & $0.70 \mathrm{a}$ & \\
\hline
\end{tabular}

Table (6). Means of leaves number of lagonaria as influenced by medium protocol, explant, sterilization time, and their interaction

\begin{tabular}{|c|c|c|c|c|c|c|c|c|}
\hline \multirow[t]{2}{*}{ Explant } & \multicolumn{7}{|c|}{ Medium protocol } & \multirow{2}{*}{$\begin{array}{c}\text { Explant } \\
\text { mean }\end{array}$} \\
\hline & 1 & 2 & 3 & 4 & 5 & 6 & 7 & \\
\hline Seed & 0.36 & 0.00 & 0.00 & 0.00 & 0.00 & 0.00 & 0.00 & $0.05 \mathrm{c}$ \\
\hline Lateral & 3.58 & 2.97 & 2.20 & 2.14 & 2.19 & 1.80 & 0.83 & $2.25 \mathrm{a}$ \\
\hline $\begin{array}{l}\text { bud } \\
\text { Shoot tip }\end{array}$ & 0.00 & 0.00 & 1.92 & 2.47 & 0.00 & 0.00 & 0.00 & $0.63 \mathrm{~b}$ \\
\hline $\begin{array}{l}\text { Medium } \\
\text { mean }\end{array}$ & 1.30ab & $0.99 \mathrm{~cd}$ & $1.40 \mathrm{ab}$ & $1.50 \mathrm{a}$ & $0.73 c$ & $0.60 \mathrm{~cd}$ & $0.30 \mathrm{~d}$ & \\
\hline 5 & 0.00 & 0.22 & 1.22 & 0.67 & 0.36 & 0.44 & 0.14 & $0.52 \mathrm{c}$ \\
\hline 10 & 0.00 & 1.00 & 1.50 & 1.78 & 0.61 & 0.61 & 0.08 & $0.94 \mathrm{~b}$ \\
\hline 15 & 2.36 & 1.75 & 1.42 & 2.17 & 1.22 & 0.75 & 0.61 & $1.47 \mathrm{a}$ \\
\hline $\begin{array}{l}\text { Medium } \\
\text { mean }\end{array}$ & $1.30 \mathrm{ab}$ & $0.99 \mathrm{~cd}$ & $1.40 \mathrm{ab}$ & $1.50 \mathrm{a}$ & $0.73 c$ & $0.60 \mathrm{~cd}$ & $0.30 \mathrm{~d}$ & \\
\hline
\end{tabular}

Data in Table (7) showed that Mercuric chloride was produced highest mean value of leaves number (1.27) lateral buds, gave a large number of leaves (3.11) when used mercuric chloride. Results showed that lateral buds gave large number of leaves (3.78) when it was sterilized for $15 \mathrm{~min}$. 
Table (7). Means of leaves number of lagonaria as influenced by explant, sterilization method, sterilization time, and their interactions

\begin{tabular}{cccc}
\hline Explant & \multicolumn{2}{c}{ Sterilization method } & Explant mean \\
\cline { 2 - 4 } & Mercuric chloride & Clorox & \\
\hline Seed & 0.06 & 0.05 & $0.05 \mathrm{c}$ \\
Lateral bud & 3.11 & 1.38 & $2.25 \mathrm{a}$ \\
Shoot tip & 0.64 & 0.61 & $0.63 \mathrm{~b}$ \\
\hline
\end{tabular}

$\begin{array}{lll}\text { Sterilization method mean } & 1.27 \mathrm{a} & 0.68 \mathrm{~b}\end{array}$

\begin{tabular}{ccccc} 
& \multicolumn{3}{c}{ Sterilization time(min.) } & \\
\cline { 2 - 4 } & 5 & 10 & 15 & \\
\cline { 2 - 4 } Seed & 0.00 & 0.00 & 0.15 & $\mathrm{c}$ \\
Lateral bud & 1.01 & 1.95 & 3.78 & $2.25 \mathrm{a}$ \\
Shoot tip & 0.56 & 0.85 & 0.46 & $0.63 \mathrm{~b}$ \\
\hline
\end{tabular}

$\begin{array}{llll}\text { Sterilization time mean } \quad 0.52 \mathrm{c} & 0.93 \mathrm{~b} & 1.46 \mathrm{a}\end{array}$

Means followed by the same letters(s) are not significantly different at $0.05 \%$ level of probability.

\subsection{Root length}

Results in Table (8) demonstrated that seeds produced the highest mean value of root length $(0.16 \mathrm{~cm})$ across medium protocols. The medium protocol (1) showed the greatest potential for root length $(0.38 \mathrm{~cm})$ across explants. The data, also, revealed that explants $\mathrm{x}$ medium protocols interaction resulted from the magnitude of response of explant to the applied protocols. In case of seeds, protocol (1) was significantly superior to all other protocols in root length $(1.12 \mathrm{~cm})$.

Table (8). Means of root length (cm) of lagonaria as influenced by medium protocol, explant, sterilization time and their interaction

\begin{tabular}{ccccccccc}
\hline Explant & \multicolumn{7}{c}{ Medium protocol } & Explant mean \\
\cline { 2 - 8 } & 1 & 2 & 3 & 4 & 5 & 6 & 7 & \\
\hline Seed & 1.12 & 0.00 & 0.00 & 0.00 & 0.00 & 0.00 & 0.00 & $0.16 \mathrm{a}$ \\
Lateral bud & 0.00 & 0.00 & 0.00 & 0.00 & 0.18 & 0.00 & 0.00 & $0.03 \mathrm{~b}$ \\
Shoot tip & 0.00 & 0.00 & 0.00 & 0.00 & 0.00 & 0.00 & 0.00 & $0.00 \mathrm{~b}$ \\
\hline Medium mean & $0.38 \mathrm{a}$ & $0.0 \mathrm{~b}$ & $0.0 \mathrm{~b}$ & $0.0 \mathrm{~b}$ & $0.06 \mathrm{~b}$ & $0.0 \mathrm{~b}$ & $0.0 \mathrm{~b}$ & \\
\hline
\end{tabular}

\begin{tabular}{ccccc}
\multirow{2}{*}{ Explant } & \multicolumn{3}{c}{ Sterilization time (min.) } & \multirow{2}{*}{ Explant mean } \\
\cline { 2 - 4 } & 5 & 10 & 15 & \\
\hline Seed & 0.00 & 0.00 & 0.48 & $0.16 \mathrm{a}$ \\
Lateral bud & 0.00 & 0.03 & 0.05 & $0.03 \mathrm{~b}$ \\
Shoot tip & 0.00 & 0.00 & 0.00 & $0.00 \mathrm{~b}$ \\
\hline Sterilization time mean & $0.0 \mathrm{~b}$ & $0.01 \mathrm{~b}$ & $0.18 \mathrm{a}$ & \\
\hline
\end{tabular}

Means followed by the same letters(s) are not significantly different at $0.05 \%$ level of probability. 


\section{2 - In vivo experiment of Lagonaria patersonii}

Table (9) presents the results of the experiments designed to find the best rooting hormone linked with the optimum soil mixture of Lagunaria patersonii seeds, terminal and subterminal cuttings. However, the tested IBA concentrations (0.0 to 10.0 ppm) were not effective with all explants used all over the 12 monthly experiments done. Besides, terminal buds didn't gave results when treated with the rooting hormone Crop plus. In addition to that, the only results obtained were in April (figure $2 \mathrm{a}$ and $2 \mathrm{~b}$ ) 2013 . The results could be presented as follows:

Table (9a). In vivo propagation of subterminal cuttings and seeds of Lagunaria

\begin{tabular}{ccccc}
\hline Soil type & $\begin{array}{c}\text { Shootlet } \\
\text { length }(\mathbf{c m})\end{array}$ & Leaves No. & Roots No. & $\begin{array}{c}\text { Root } \\
\text { length(cm) }\end{array}$ \\
\hline Sand + Peat & $4 \pm 0.6$ & $4.8 \pm 2.2$ & $2.2 \pm 0.84$ & $3.26 \pm 1.9$ \\
Peat + perlite & $4.7 \pm 2.5$ & $4.4 \pm 2.7$ & $1.6 \pm 4.2$ & $0.68 \pm 0.72$ \\
Peat+ perlite +Sand & $4.3 \pm 3.2$ & $3.6 \pm 5.8$ & $2.3 \pm 5.8$ & $2.9 \pm 5.88$
\end{tabular}

Table (9b). In vivo seed germination of Lagunaria

\begin{tabular}{lcllc}
\hline \multicolumn{1}{c}{ Soil type } & $\begin{array}{c}\text { Shootlet } \\
\text { length(cm) }\end{array}$ & Leaves No. & Roots No. & $\begin{array}{c}\text { Root } \\
\text { length(cm) }\end{array}$ \\
\hline $\begin{array}{l}\text { Peat } \\
\text { perlite }\end{array}$ & $5 \pm 3.6$ & $4.9 \pm 6$ & $2 \pm 6.2$ & $2.4 \pm 6.5$ \\
\hline
\end{tabular}

Data presents mean \pm S.E.

\section{Molecular makers experiment of Lagunaria (Analysis of RAPD Data)}

\subsection{Screening of polymorphism in Lagunaria original plant and its somaclones}

Ten primers were screened for their ability to amplify the genomic DNA of the Lagunaria mother plant and its plantlets. The number of DNA fragments amplified ranged from 10 to 14 fragments per primer depending on the primer and the DNA sample. These values are rather high for RAPD amplification, compared to the average numbers of amplified bands recorded in other crops; namely three fragments in Triticum turgidium L. (Joshi and Nguyen, 1993), 4.3 fragments in Solanum tuberosum L. (Masuelli et al., 1995) but much lower than that reported in Chrysanthemum varieties and their somaclones (Martin et al., 2002). The size of fragments ranged from 200 to $1600 \mathrm{bp}$. A total of 62 fragments were produced by the primers. Previously, RAPD markers tightly linked to the locus controlling Lagunaria plant type were identified by Scovel et al (1998). Genotype identification of ornamental species by RAPD had been reported by Benedetti et al (2001). Recently, RAPD analysis was used for the identification of molecular markers associated with flower longevity that could be used for the early screening of $F_{1}$ progenies with a long vase life (Benedetti et al., 2003). A total of 465 primers were 
used to identify RAPD markers associated with genes controlling wilt resistance in carnation by Onozaki et al., (2003). They reported that 11 RAPD markers were linked to genes for resistance to bacterial wilt, and 3 linkage groups were identified by linkage analysis. Recently, PCR - based markers for cut flower longevity in carnation have been reported (Benedetti et al., 2005). Williams et al. (1990) reported that polymorphism among individuals could arise through nucleotide change that prevented amplification by introducing either a mismatch at one priming site, deletion of a priming site, insertions that rendered priming sites too distant to support amplification and insertions or deletions that change the size of the amplified product. The PCR technique proved to be a powerful tool for the identification of polymorphism in cereals. Using wheat, barely-rye, wheat-barely and rice addition lines, Weinging and Landgridge (1991) detected polymorphism, using conserved, semi-random and random primers. With different combinations of primers, they were able to detect both inter-and intraspecific diversities.

\subsection{Cluster analysis}

One of the goals of the present study was to investigate the efficiency of RAPD markers in determining, accurately, the genetic relationship between somaclones and their parents. The RAPD markers, produced by ten primers, were used to construct a similarity matrix. Simple matching coefficient, ranging from 0.32 to 0.91 , suggested a broad genetic base for carnation genotypes. the genetic similarity estimates of the 153 pairwise comparisons among the carnation cultivars and their somaclones, based on 52 polymorphic bands. These results indicated that RAPD technique could be successfully applied to ornamental crops. DNA markers are currently used to identify varieties and to analyze inter - and intra - specific genetic relatedness (Torres et al., 1993; Ben - Meir and Vainstein, 1994; Yamagishi, 1995; Rajapakse and Ballard., 1997). Recently, genetic diversity of Dianthus chinensis and Dianthus caryophyllus with RAPD analysis was reported by Wen et al. (2003). You Bo et al., (2004) used RAPD technique to amplify the genomic DNA fragments of 87 carnation cultivars. Their results revealed that the 87 cultivars were divided into 10 groups at the DNA level. These results have significance for the genetic breeding and identification of cultivars of Lagunaria.

The present study indicated that the use of RAPD technique was sensitive and powerful to detect genetic variation at the level of DNA among Lagunaria cultivars and their plantlets(figure 3).

In conclusion, the suitable protocol to regeneration the Lagunaria which in endangered plant was MS free growth regulators and the best rooting medium was 1/4 MS. RAPD analysis was also applied to detect the genetic polymorphism among Lagonaria plantlet and their original parents. The study also indicated that the use of RAPD technique was sensitive and powerful to detect genetic variation at the level of DNA among Lagunaria cultivars and their plantlets. 


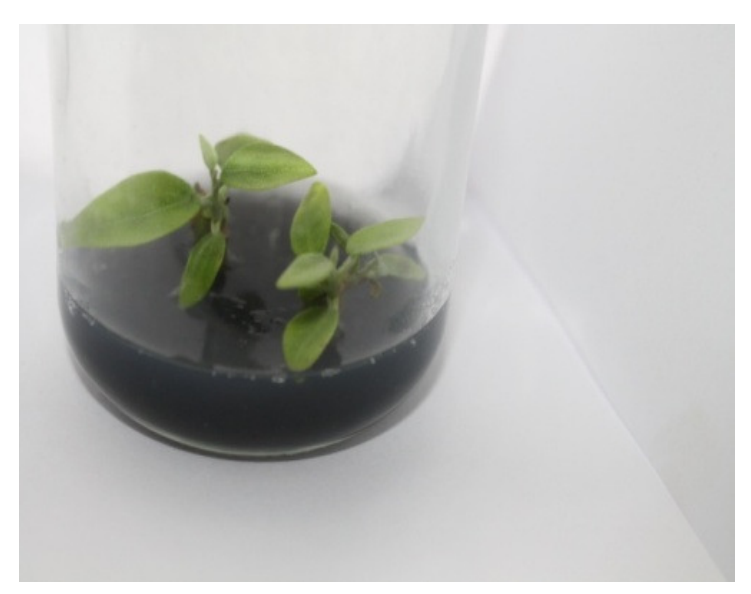

Figure 1a: In vitro shoot formation of Lagunaria derived from lateral buds

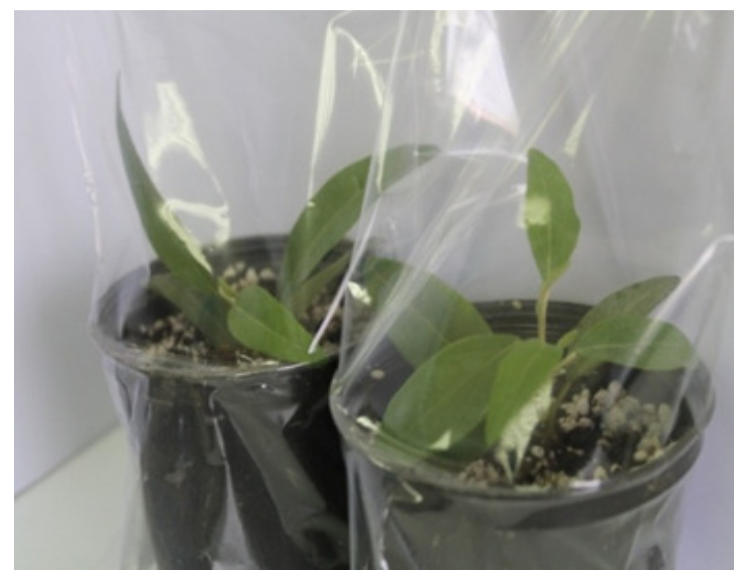

Figure 1c: Whole Lagunaria plant regenerated covered with polyethylene bags for cclimatization.

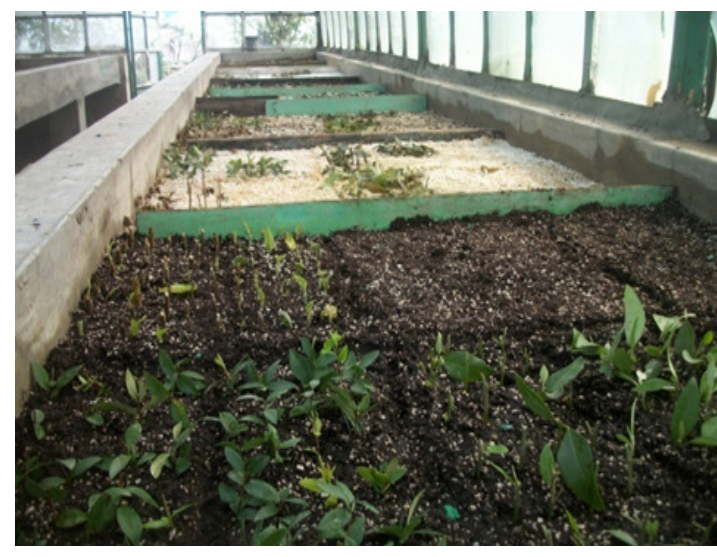

Figure 2a: Lagunaria cuttings cultured in the reenhouse on different soil mixtures.

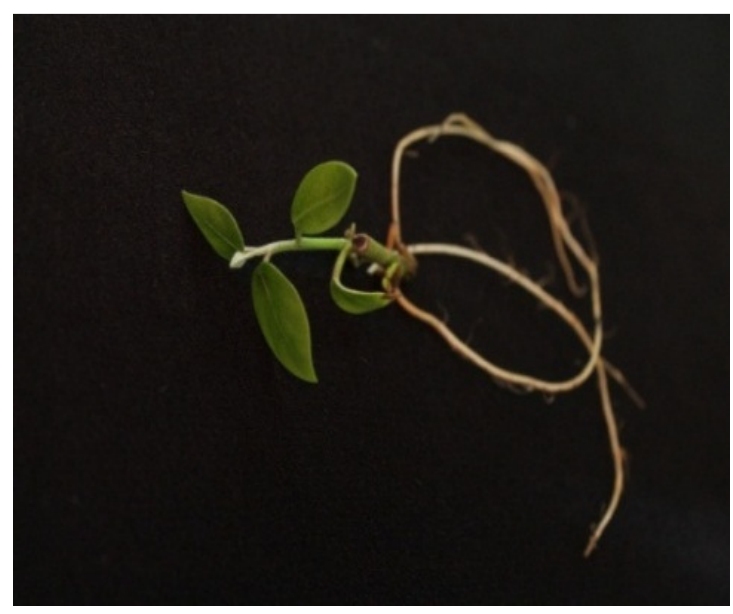

Figure 1b: Lagunaria plantlet.

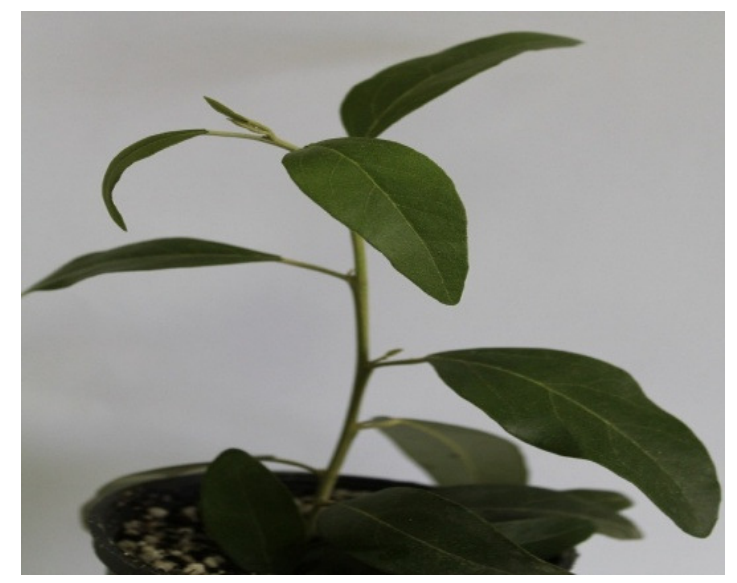

Figure 1d: Whole Lagunaria plant regeneration established in the greenhouse.

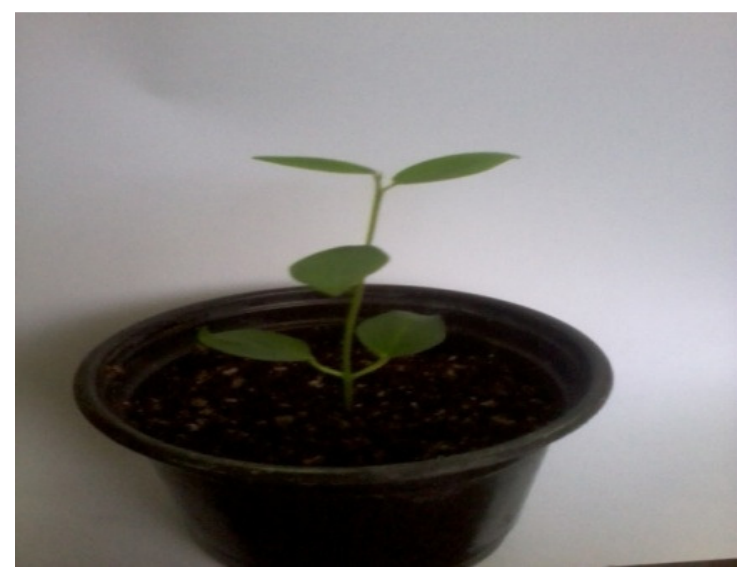

Figure 2b: In vivo seed germination of Lagunaria. 

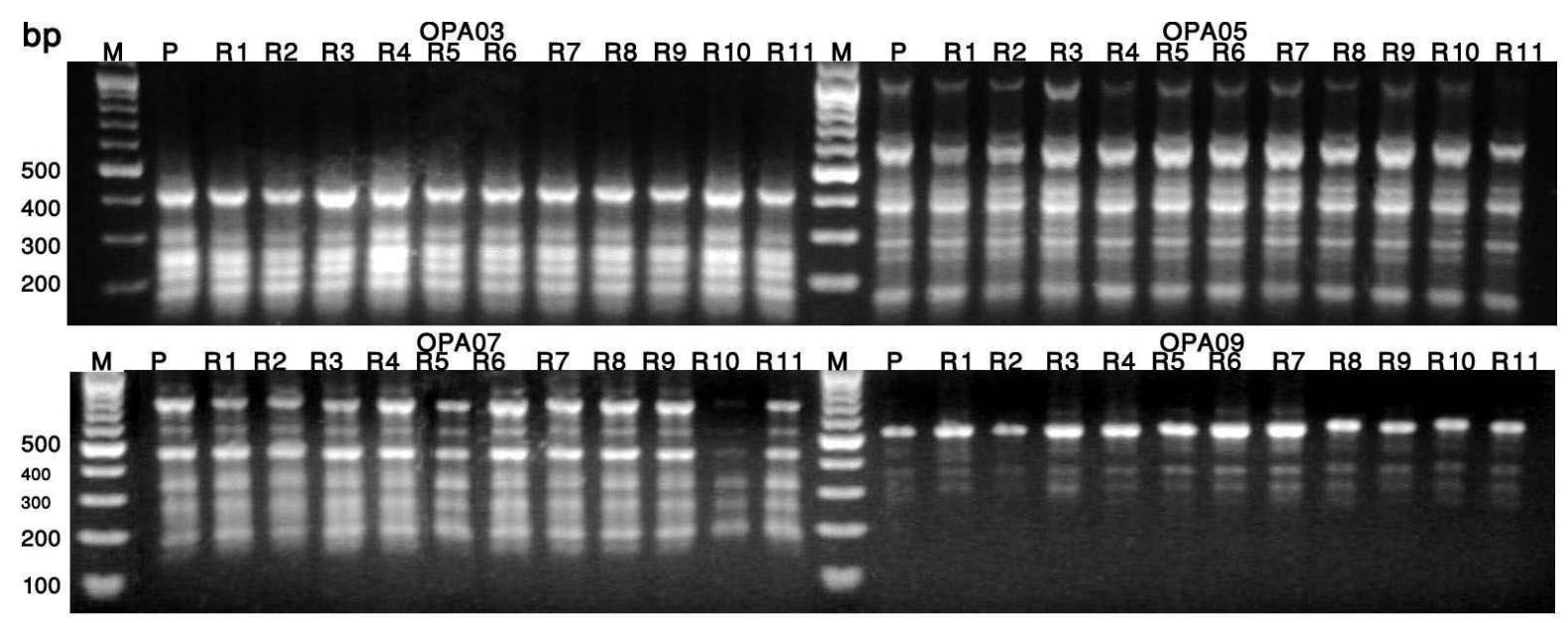
OPB 10

OPB 12

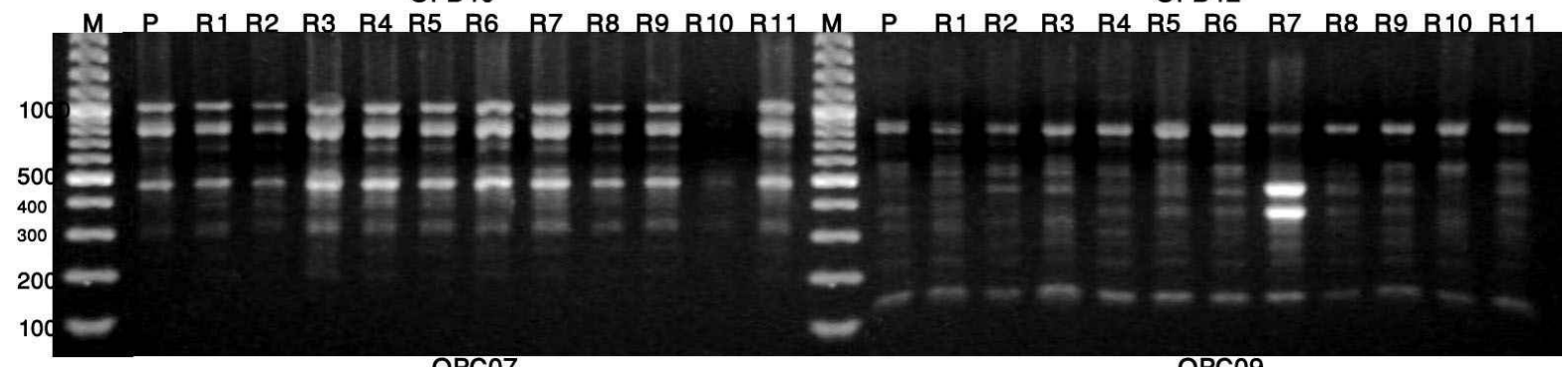

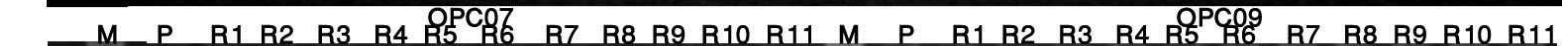
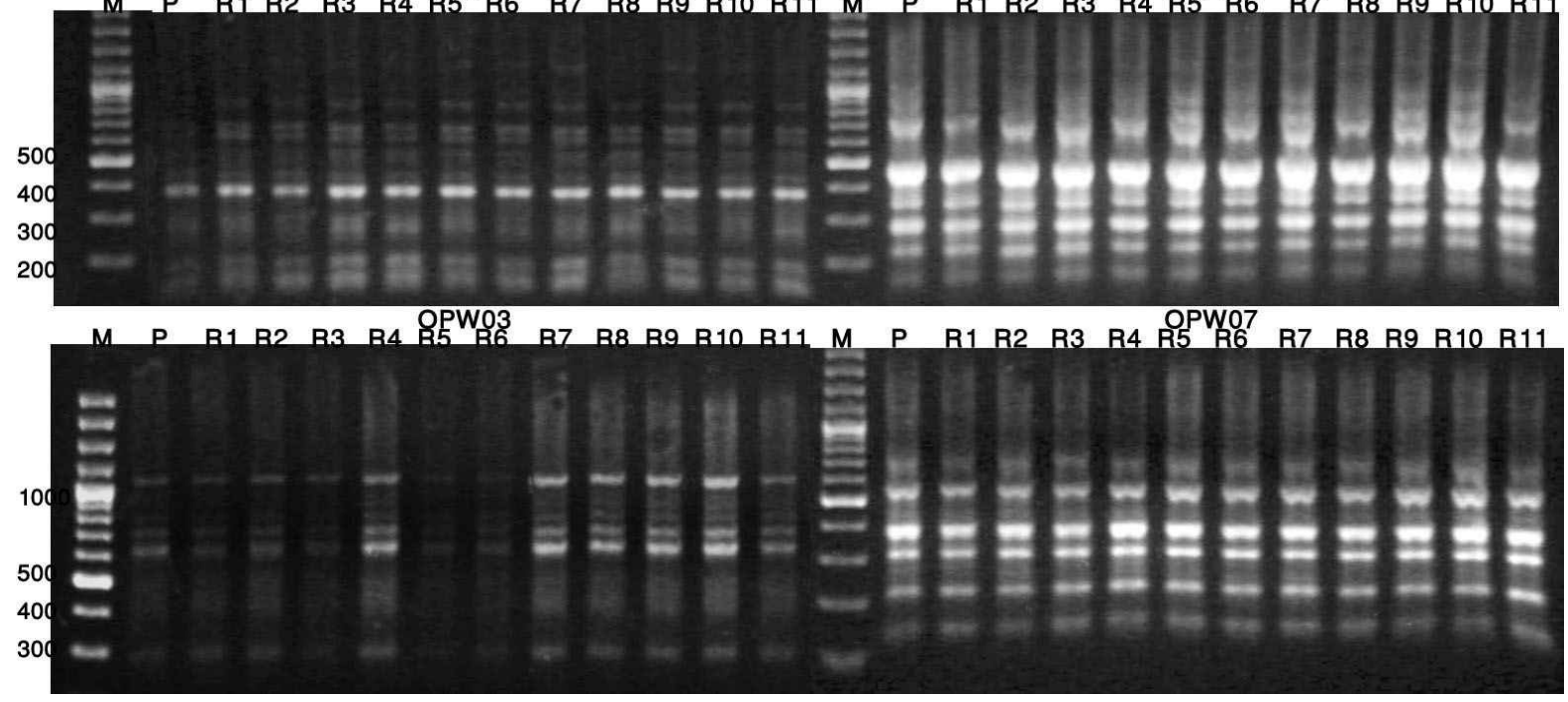

Figure 3: RAPD analysis for Lagunaria patersonii mother plant and its plantlets. 


\section{Acknowledgement}

The authors would like to express great thanks to the agricultural university and the agricultural Research Center.

\section{REFERENCES}

Aiello, D., Parlavecchio G. and Vitale, D. (2008). First Report of Damping-Off Caused by Rhizoctonia solani AG-4 on Lagunaria patersonii .PI. Dis., 92, 5:836.

Ben-Meir, H. , and Vainstein, A. (1994) Assessment of genetic relatedness in roses by DNA fingerprint analysis. Sci. Hort., 58(1-2) : 115-121.

Benedetti, L. D. , Mercuri, A., Bruna, S., Burchi, G. and Schiva, T. (2001). Genotype Identification of Ornamental Species by RAPD Analysis. Acta Hort., 546:391-394.

Benedetti, L. D. , Burchi, G., Bruna, S., Mercuri, A. and Schiva, T. (2003) .Use of molecular markers to improve cut flowers longevity in carnation. Acta Hort. 624: XXVI Interna. Hort. Cong.: Elegant Sci. Flori.

Benedetti, L D. , Braglia, L ., Bruna, S., Burchi, G . Mercuri, A.and Schiva.(2005). PCR-based Markers and Cut Flower Longevity in Carnation Acta Hort. 683, ISHS (437-443).

Chaturvedi, HC., and Sharma, M. (1989).In vitro production of cloned plants of jojoba (Simmondsia chinensis L.) through shoot proliferation in long term culture.Plant Sci., 63: 199-207.

Jaccard, P. (1980). Nouvelles recherches sur la distribution lorale. Bull. Soc. Vaud. Sci. Nat.,44:223-270.

John, H W. ( 2006). Ph.D. Thesis, Uni. St. Dep.Agri. Agri. Res. Ser., Sys .Bot. Myc. Lab., Bldg. 011A, Beltsville Agri. Res. Cen. (BARC-West), Beltsville, MD 20705-2350 U.S.A.; (http://www.ars-gri).

Joshi CP. and Nguyen, H.T. (1993) . RAPD (random amplified polymorphic DNA) analysis based intervarietal genetic relationships among hexaploid wheats. Plant Sci 93: 95-103

Martin ,C. , Uberhuaga, C .and Perez, C . (2002). Application of RAPD markers in characterization of chrysanthemum varieties and the assessment of somaclonal variation. Euphytica, 127: 247-53.

Masuelli, R. W., Tanimoto, E. Y. and Brown C. R. (1995). Irregular meiosis in a somatic hybrid between $\mathrm{S}$. bulbocastanum and $\mathrm{S}$. tuberosum detected by species-specific PCR markers and cytological analysis. Theo and App Gene, 91 (3) 401.

Murashig, T. ,and Skoog, F. (1962). A revised medium for rapid growth and bioassay with Tobacco tissue cultures. Physiol Plant. 15:473 - 479.

Nitsch, J.P. , and Nitsch, C. (1969). Haploid plants from pollen grains. Sci., 163: 85-87.

Onozaki, T. , Tanikawa N., Taneya, M., Kubo K., Funayama, T., Ikeda, H.and Shibata, M. ( 2003). A RAPD-derived STS markeris linked to a bacterial wilt (Burkholderia caryophylli) resistance gene in carnation. Euphytica 138: 255262.

Rajapakse S. , and Ballard R.E. (1997) Cultivar identification using molecular methods. In: Geneve RL. Preece JE. Merkle SA (Ed) Biotechnology of 
ornamental plants. CAB International. Wallinford. UK (Biotechnology in agriculture series), 16:153-164..

SAS Institute Inc. (1985) SAS/STAT. Guide for personal computers. version $6,4^{\text {th }}$ ed. vol. 2 Cary. NC, USA.

Scovel, G. ; Ben-Meir, H., Ovadis, M., Itzhaki ,H. and Vainstein, A.( 1998). RAPD and RFLP markers tightly linked to the locus controlling carnation (Dianthus caryophyllus) flower type. Theor. Appl. Genet. ,96: 117-122.

Steel, R. G. D. ,and Torrie, J. H. (1980). Principles and Procedures of Statistics. A Biometrical Approach. (2 ${ }^{\text {nd }}$ edition). McGraw Hill Book.

Theresa. L. (2010). Herbarium Orman Botanical Garden, Giza, Egypt. Personal communication.

Torres, A. M., Weeden N. F ., and Martn A. (1993).Linkage among isozyme RFLP and RAPD markers in Vicia faba. Theor .Appl .Genet, 85:937-945.

USDA (2006).Plants Profile .http://plants.usda.gov.

USFWS. (2006). Threatened and endangered species system (TESS). From http://ecos.fws.gov/tess public/TESSWebpage.

Weining, B. ,and Langridge P. (1991).Identification and Mapping Polymorphism in Cereals Based on PCR. Theor. Appl. Genet.,82: 209-216.

Wen, W. , YouMing, C ., HuiYu ,Z., and MinRen, H . (2003). Genetic diversity of Dianthus chinensis L. and D. caryophyllusL. with RAPD. J. Nanj. For Univ.,27 (4):72-74.

Williams, J. G. K., Kubelik, A. R., Livak, K. J., Rafalski ,J. A., and Tingey, S. V. (1990). DNA polymorphisms amplified by arbitrary primers are useful as genetic markers. Nucleic Acids Research, 18:6531-6535.

Yamagishi, M. ,( 1995). Detection of section-specific random amplified polymorphic DNA (RAPD) markers in Lilium. Theor. Appl. Genet., 91: 830-835.

You B. O. S., Chun L ., Jing M ., Xijun M . and Ming Y. (2004). RAPD identification of different carnation cultivars. Acta Hort. Sin.,31(1):109-111. 


\section{الملخص العريى \\ الحفاظ على نبات اللاجوناريا باستخدام طرق الاكثار المعملى والحقلى \\ مى أحمد ابراهيم' و نجلاء محمد ابراهيم' وعلى ابراهيم على عبيدو' 1- مركز البحوث الزراعية - كلية زراعة ساباباشا- جامعة الاسكندرية}

اللاجوناريا من أشجار الزينة المهدة بالانقراض فى مصر وهى موجودة بعدد قليل جدا وأكثرها مصاب

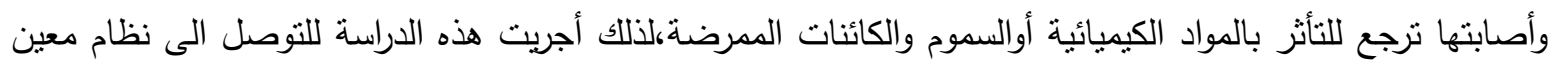
نسنطيع من خلاله انتاج عدد كبير من هذه النباتات معطليا فلذلك تمت زراعة كل من البذور والعقل الجانبية والقمة

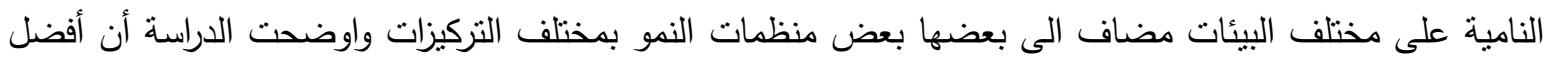
بيئة كانت بيئة ال ام اس وبيئة التجزير كانت ربع ام اس وتم تحليل النباتات الناتجة من الزراعة عن طريق تكنيك الرابد وأثنتت التحاليل تطابقها مع النبات الام. بلهن 